\title{
PENGARUH KECERDASAN EMOSIONAL TERHADAP PENYELESAIAN TUGAS TERSTRUKTUR MAHASISWA PRODI PENDIDIKAN TEKNIK BANGUNAN UPI
}

\author{
Sri Rahayu ${ }^{1}$ dan Rieske Iswardhany ${ }^{2}$ \\ ${ }^{1,2}$ Universitas Pendidikan Indonesia \\ Email: srirahayu@upi.edu
}

\begin{abstract}
ABSTRAK
Kajian ini bertujuan sebagai berikut 1) memperoleh gambaran mengenai kecerdasan emosional mahasiswa Prodi Pendidikan Teknik Bangunan UPI; 2) memperoleh gambaran mengenai penyelesaian tugas terstruktur mahasiswa Prodi Pendidikan Teknik Bangunan UPI; 3) mengetahui besarnya pengaruh kecerdasan emosional terhadap penyelesaia tugas terstruktur. Kajian ini merupakan penelitian deskriptif kuantitatif. Metode yang digunakan adalah survey dengan teknik pengumpulan data menggunakan teknik dokumentasi dan angket skala Likert. Berdasarkan hasil kajian diperoleh secara keseluruhan gambaran kecerdasan emosional memiliki persetase 57,46\% yang termasuk kedalam kriteria sedang, untuk penyelesaian tugas terstruktur secara keseluruhan memiliki persentase 43,42\% yang termasuk ke dalamkriteria sedang dan berdasarkan hasil perhitungan Koefisien Determinasi (KD) untuk mengetahui seberapa besar kontribusi kecerdasan emosional terhadap penyelesaian tugas terstruktur mahasiswa dapat disimpulkan bahwa kecerdasan emosional memberikan kontribusi sebesar 19,52\% terhadap penyelesaian tugas terstruktur.
\end{abstract}

Kata kunci: Kecerdasan emosional, penyelesaian tugas terstruktur

\begin{abstract}
This study aims as follows 1) obtain a picture of the emotional intelligence of students in the Building Engineering Education, Indonesia University of Education; 2) obtain an overview of the structured task completion of students in the Building Engineering Education, Indonesia University of Education; 3) know the magnitude of the influence of emotional intelligence on the completion of structured tasks. This research is quantitative descriptive. The method used is a survey with data collection techniques using a Likert scale documentation and questionnaire technique. Based on the results of the study, it is obtained overall the picture of emotional intelligence has a percentage of $57.46 \%$ which is included in the medium criteria, for the completion of structured tasks as a whole has a percentage of $43.42 \%$ which is included in the medium criteria and based on the calculation of the coefficient of determination to find out how much the contribution emotional intelligence on the completion of structured tasks students can be concluded that emotional intelligence contributes $19.52 \%$ to the completion of structured tasks.
\end{abstract}

Keywords: Emotional intelligence, completion of structured tasks

\section{PENDAHULUAN}

Pembangunan dan kemajuan suatu bangsa terletak pada sumber daya manusia yang berkualitas. Hal tersebut dapat diwujudkan dengan mengembangkan pendidikan yang tidak hanya memperhatikan aspek intelektualnya saja, tetapi juga kemampuan emosinya.

Prestasi belajar merupakan sebuah gambaran konkrit keberhasilan proses belajar mengajar yang berlangsung di institusi pendidikan, prestasi belajar juga dapat menjadi tolak ukur dari tingkat pemahaman peserta didik terhadap materi tertentu yang telah diberikan, setelah peserta didik mengalami proses belajar pada jangka waktu tertentu.

Kadang kala dijumpai beberapa kasus, seorang peserta didik mempunyai IQ cukup tinggi tetapi mengalami kesulitan belajar di institusi pendidikan 


\section{Pengaruh Kecerdasan Emosional... (Sri/ hal. 24-36)}

sehingga Indeks Prestasinya jelek. Kasus ini dikenal dengan anak berprestasi di bawah kemampuannya (under achievement).

Dalam suatu studi, murid-murid yang mempunyai IQ diatas rata-rata, dan nilai raportnya buruk, ternyata setelah dilakukan pengujian-pengujian neoropsikologis, murid-murid tersebut memiliki kortek-frontal yang cacat. Kortek frontal adalah wilayah otak yang bertanggung jawab untuk ingatan, yang merupakan bagian sirkuit kerja sama antara nalar dan perasaan. Jadi, apabila manusia sedang kacau perasaannya, secara emosional bisa berakibat tidak bisa berpikir jernih (Mudjijana, 2004:84).

Pendidikan di Indonesia masih menekankan pada nilai akademik, kecerdasan otak atau kita mengenalnya sebagai Intelligence Quotient (IQ). Pendidikan yang mengajarkan kecerdasan emosi meliputi pembelajaran tentang integritas, kejujuran, komitmen, visi, kreativitas, ketahanan mental, kebijaksanaan dan keadilan jarang ditemukan. Kemampuan intelektual dianggap lebih menjawab persoalan pendidikan dibandingkan dengan kemampuan lainnya. Paradigma pembelajaran seperti ini diharapkan dapat diubah, karena kecerdasan otak saja tidak cukup bagi mahasiswa tetapi juga harus mempertimbangkan kecerdasan emosi atau Emotional Quotient (EQ) yang pada dasarnya dimiliki oleh setiap manusia.

Menurut Goleman (2005:44), kecerdasan intelektual (IQ) hanya menyumbang $20 \%$ bagi kesuksesan, sedangkan $80 \%$ adalah sumbangan faktor kekuatan-kekuatan lain, diantaranya adalah kecerdasan emosional (EQ).
Di Universitas Pendidikan Indonesia (UPI) pada Prodi Pendidikan Teknik Bangunan, terdapat Mata Kuliah Keahlian (MKK) yang harus ditempuh oleh mahasiswa. Mata Kuliah Keahlian adalah mata kuliah wajib yang harus diambil oleh mahasiswa Prodi Pendidikan Teknik Bangunan UPI.

Aspek penilaian dalam Mata Kuliah Keahlian yaitu: kehadiran, UTS, UAS dan penyelesaian tugas terstruktur ysng merupakan prasyarat untuk kelulusan pada mata kuliah ini, jika tugas terstruktur ini tidak diselesaikan maka mahasiswa yang bersangkutan dinyatakan tidak lulus dari Mata Kuliah Keahlian ini.

Mata Kuliah Keahlian (MKK) yang memiliki tugas terstruktur diantaranya yaitu Struktur Kayu, Struktur Beton I dan Struktur Baja II. Pengerjaan tugas terstruktur bersifat perorangan, maka mahasiswa dituntut untuk lebih mengoptimalkan lagi kegiatan belajarnya sehingga dapat mengerjakan tugas terstruktur tersebut dengan benar dan dapat diselesaikan tepat pada waktunya.

Dalam pengerjaan tugas terstruktur dibutuhkan situasi diri yang cukup tenang, hal ini berkaitan dengan konsentrasi dalam proses penyelesaian tugas terstuktur. Emosi yang mendalam mengurangi konsentrasi dalam belajar dan ini akan mengganggu serta menghambat dalam penyelesaian tugas terstruktur sehingga hasilnya pun tidak akan maksimal. Hal ini sesuai dengan pendapat Amy A. Yuningsih (2009:11) mengenai faktor yang mempengaruhi proses belajar:

a. Faktor dari dalam individu (internal), yang terdiri dari.

- Faktor jasmaniah, yaitu faktor kesehatan dan faktor cacat tubuh. 
Pengaruh Kecerdasan Emosional... (Sri/ hal. 24-36)

- Faktor psikologis, yaitu kecerdasan (kecerdasan intelektual, kecerdasan emosional dan kecerdasan spiritual), motif, minat, bakat, kematangan, dan kesiapan.

- Faktor kelelahan, yaitu kelelahan jasmani dan kelelahan rohani.

b. Faktor dari luar individu (eksternal), yang terdiri dari; keluarga, lingkungan kampus, media/alat pengajaran, metode mengajar, hubungan antara dosen dan mahasiswa, hubungan antara mahasiswa dan mahasiswa, kebiasaan belajar mahasiswa dan masyarakat.

Mata Kuliah Struktur Kayu, Struktur Beton I dan Struktur Baja II dipilih oleh peneliti karena ketiga mata kuliah tersebut mempunyai tugas testruktur yang menitikberatkan pada perhitungan, perencanaan, dan penggambaran dengan benar, tepat dan sesuai ketentuannya, kemudian pertimbangan lainnya karena adanya keterbatasan responden sebab responden yang diteliti harus sama, yakni responden yang telah lulus pada ketiga mata kuliah terstruktur, agar saat menentukan sampel peneliti tidak kesulitan.

Berdasarkan pengamatan sementara setelah mengikuti perkuliahan Mata Kuliah Struktur Kayu, Struktur Beton I dan Struktur Baja II, ditemukan berbagai macam kondisi yang sering kali tidak berjalan lancar dalam penyelesaian tugas terstruktur yaitu sering terdapat mahasiswa Prodi Pendidikan Teknik Bangunan dinyatakan belum lulus ataupun tidak lulus dan diharuskan untuk mengontrak kembali. Karena mahasiswa tidak dapat menyelesaikan tugas terstruktur tepat pada waktunya ataupun tidak mengerjakan tugas terstruktur.

Penelitian Imam (2007) mengenai kecerdasan emosional pada mahasiswa Jurusan Teknik Sipil UPI angkatan 20032004, menggambarkan mahasiswa JPTS UPI memiliki kecerdasan emosional relatif baik. Hal ini terbukti lebih dari 54\% responden kecerdasan emosional berada pada kriteria tinggi. Hal tersebut menunjukkan mahasiswa JPTS UPI baik dalam kecerdasan emosionalnya.

Berkaitan peranan kecerdasan emosional dalam meraih kesuksesan, khususnya kesuksesan sebagai seorang mahasiswa yang diukur dari prestasi akademik. Dalam hal ini mendorong peneliti untuk meneliti "Pengaruh kecerdasan emosional dengan penyelesaian tugas terstruktur". Penelitian sebelumnya oleh Imam (2007) membuktikan adanya pengaruh positif dan signifikan kecerdasan emosional mahasiswa terhadap prestasi belajar mata kuliah mekanika teknik. Penelitian lainnya Lia Dahliani (2008) mengenai faktorfaktor yang mempengaruhi terhambatnya penyelesaian tugas terstruktur Teknik Irigasi I di program studi Pendidikan Teknik Sipil UPI. Bahwa keinginan mahasiswa Prodi Pendidikan Teknik Sipil UPI untuk menyelesaikan tugas terstruktur teknik Irigasi I sudah cukup baik. Hal ini menunjukan mahasiswa Prodi Pendidikan Teknik Bangunan kurang optimal. Salah satu faktor yang paling dominan yang mempengaruhi terhambatnya penyelesaian tugas terstruktur Teknik Irigasi I adalah faktor psikologi.

Sejalan dengan apa yang diuraikan sebelumnya, dapat dikatakan bahwa proses penyelesaian tugas terstruktur dipengaruhi oleh beberapa faktor antara lain, faktor 
Pengaruh Kecerdasan Emosional... (Sri/ hal. 24-36)

eksternal misalnya lingkungan belajar di kampus. Selain itu dapat dipengaruhi oleh faktor internal misalnya tingkat kecerdasan, bakat ataupun minat mahasiswa.

Merujuk pada pemikiran di atas, maka untuk memperoleh gambaran yang sebenarnya maka penulis akan mengadakan kajian dengan judul "Pengaruh Kecerdasan Emosional terhadap Penyelesaian Tugas Terstruktur Mahasiswa Prodi Pendidikan Teknik Bangunan UPI."

\section{METODE}

Dalam kajian ini akan menggunakan pendekatan kuantitatif, karena dalam penelitian ini merumuskanhipotesis. Sedangkan untuk metode penelitiannya menggunakan metode deskriptif, Dengan metode ini, penulis berusaha memperoleh gambaran secara sistematis tentang "Pengaruh Kecerdasan Emosional terhadap Penyelesaian Tugas Terstruktur". Dengan metode ini, penulis berusaha memperoleh gambaran secara sistematis tentang "Pengaruh Kecerdasan Emosional terhadap Penyelesaian Tugas Terstruktur". Pengumpulan data dalam kajian ini dilakukan dengan menggunakan teknik dokumentasi dan metode angket. Teknik sampel digunakan propotional stratified random sampling

\section{HASIL DAN PEMBAHASAN}

\section{Deskripsi Variabel Kecerdasan Emosional (X)}

Kecerdasan Emosional pada mahasiswa Program Studi Pendidikan Teknik Bangunan UPI akan dijelaskan per indikator. Gambaran rata-rata dari indikator yang diungkap dari variabel $\mathrm{X}$ dapat ditunjukkan pada Tabel 1.

Berdasarkan hasil perhitungan, diperoleh deskripsi indikator mampu mengenali emosi yang sedang dirasakan diri sendiri memiliki persentase sebesar $55,79 \%$ dari kriteria sedang, indikator mampu mengenali kadar perasaan dengan tindakan memiliki persentase sebesar $57,37 \%$ dari kriteria sedang, indikator mampu mengenali kepercayaan diri persentasenya sebesar 50,53\% dari kriteria sedang, indikator mampu untuk mengendalikan diri memiliki persentase sebesar 55,09\% dari kriteria sedang, indikator mampu memusatkan perhatian pada kegiatan yang sedang berlangsung persentasenya sebesar $61,23 \%$ dari kriteria tinggi, indikator mampu menunda kesenangan sesaat untuk mendapatkan hasil yang baik persentasenya sebesar $48,42 \%$ dari kriteria sedang, indikator dorongan untuk berprestasi memiliki persentase sebesar $55,53 \%$ dari kriteria sedang, indikator mampu untuk optimis persentasenya sebesar $62,11 \%$ dari kriteria tinggi, indikator mampu merasakan perasaan orang lain persentasenya sebesar $54,21 \%$ dari kriteria sedang, indikator menerima atau mengerti perspektif orang lain persentasenya sebesar $61,84 \%$ dari kriteria tinggi, indikator dapat memulai dan mempertahankan interaksi persentasenya sebesar 53,68\% dari kriteria sedang, indikator mampu menyatakan emosi melalui komunikasi yang sesuai memiliki persentase sebesar $65,26 \%$ dari kriteria tinggi, kemudian indikator mampu menyesuaikan emosi dengan tepat dalam berinteraksi dengan orang lain memiliki persentase sebesar $61,05 \%$ dari kriteria tinggi, selanjutnya indikator mampu membaca situasi dalam hubungan 
Pengaruh Kecerdasan Emosional... (Sri/ hal. 24-36)

interpersonal memiliki persentase sebesar

$62,37 \%$ dari kriteria tinggi.

Tabel 1. Presentasi Indikator Pada Variabel X

\begin{tabular}{|c|c|c|c|}
\hline Aspek & Indikator & Rata-Rata & Persentase \\
\hline \multirow{5}{*}{ Mengenali emosi diri } & Mampu mengenali emosi yang sedang dirasakan diri & & \\
\hline & sendiri & 2,79 & $55,79 \%$ \\
\hline & Mampu mengenali kadar perasaan dengan tindakan. & 2,87 & $57,37 \%$ \\
\hline & Mampu mengenali kepercayaan diri & 2,53 & $50,53 \%$ \\
\hline & Mampu untuk mengendalikan diri & 2,75 & $55,09 \%$ \\
\hline \multirow[t]{2}{*}{ Mengelola emosi } & $\begin{array}{l}\text { Mampu memusatkan perhatian pada kegiatan yang } \\
\text { sedang berlangsung }\end{array}$ & 3,06 & $61,23 \%$ \\
\hline & $\begin{array}{l}\text { Mampu menunda kesenangan sesaat untuk mendapatkan } \\
\text { hasil yang baik }\end{array}$ & 2,42 & $48,42 \%$ \\
\hline \multirow{2}{*}{$\begin{array}{l}\text { Memotivasi diri } \\
\text { sendiri }\end{array}$} & Dorongan untuk berprestasi & 2,78 & $55,53 \%$ \\
\hline & Mampu untuk optimis & 3,11 & $62,11 \%$ \\
\hline \multirow{3}{*}{$\begin{array}{l}\text { Mengenali emosi } \\
\quad \text { orang lain }\end{array}$} & Mampu merasakan perasaan orang lain & 2,71 & $54,21 \%$ \\
\hline & Menerima atau mengerti perspektif orang lain & 3,09 & $61,84 \%$ \\
\hline & Dapat memulai dan mempertahankan interaksi & 2,68 & $53,68 \%$ \\
\hline \multirow{5}{*}{ Membina hubungan } & $\begin{array}{l}\text { Mampu menyatakan emosi melalui komunikasi yang } \\
\text { sesuai }\end{array}$ & 3,26 & $65,26 \%$ \\
\hline & $\begin{array}{l}\text { Mampu menyesuaikan emosi dengan tepat dalam } \\
\text { berinteraksi dengan orang lain. }\end{array}$ & 3,05 & $61,05 \%$ \\
\hline & Mampu membaca situasi dalam hubungan interpersonal & 3,12 & $62,37 \%$ \\
\hline & Kecerdasan emosional & 2,87 & $57,46 \%$ \\
\hline & Nilai Ideal & 5,00 & $100,00 \%$ \\
\hline
\end{tabular}

Berdasarkan hasil perhitungan, diperoleh deskripsi indikator mampu mengenali emosi yang sedang dirasakan diri sendiri memiliki persentase sebesar $55,79 \%$ dari kriteria sedang, indikator mampu mengenali kadar perasaan dengan tindakan memiliki persentase sebesar $57,37 \%$ dari kriteria sedang, indikator mampu mengenali kepercayaan diri persentasenya sebesar $50,53 \%$ dari kriteria sedang, indikator mampu untuk mengendalikan diri memiliki persentase sebesar 55,09\% dari kriteria sedang, indikator mampu memusatkan perhatian pada kegiatan yang sedang berlangsung persentasenya sebesar $61,23 \%$ dari kriteria tinggi, indikator mampu menunda kesenangan sesaat untuk mendapatkan hasil yang baik persentasenya sebesar $48,42 \%$ dari kriteria sedang, indikator dorongan untuk berprestasi memiliki persentase sebesar $55,53 \%$ dari kriteria 28 sedang, indikator mampu untuk optimis persentasenya sebesar $62,11 \%$ dari kriteria tinggi, indikator mampu merasakan perasaan orang lain persentasenya sebesar $54,21 \%$ dari kriteria sedang, indikator menerima atau mengerti perspektif orang lain persentasenya sebesar $61,84 \%$ dari kriteria tinggi, indikator dapat memulai dan mempertahankan interaksi persentasenya sebesar $53,68 \%$ dari kriteria sedang, indikator mampu menyatakan emosi melalui komunikasi yang sesuai memiliki persentase sebesar $65,26 \%$ dari kriteria tinggi, kemudian indikator mampu menyesuaikan emosi dengan tepat dalam berinteraksi dengan orang lain memiliki persentase sebesar $61,05 \%$ dari kriteria tinggi, selanjutnya indikator mampu membaca situasi dalam hubungan interpersonal memiliki persentase sebesar $62,37 \%$ dari kriteria tinggi. 
Pengaruh Kecerdasan Emosional... (Sri/ hal. 24-36)

Jadi indikator terendah adalah mampu menunda kesenangan sesaat untuk mendapatkan hasil yang baik mencapai $48,42 \%$ dari kriteria sedang dan indikator tertinggi adalah mampu menyatakan emosi melalui komunikasi yang sesuai mencapai $65,26 \%$ dari kriteria tinggi. Secara keseluruhan gambaran kecerdasan emosional memiliki persentase 57,46\% yang termasuk ke dalam kriteria sedang.

\section{Deskripsi Variabel Penyelesaian Tugas Terstruktur (Y)}

Sedangkan untuk deskripsi rata-rata dari indikator yang diungkap dari variabel Y dapat ditunjukan pada Tabel 2.

Tabel 2. Presentasi Indikator Pada Variabel Y

\begin{tabular}{llcc}
\hline No & \multicolumn{1}{c}{ Indikator } & Rata-Rata & Persentase \\
\hline 1 & Lingkup pemahaman dan tujuan pengerjaan & 0,88 & $43,86 \%$ \\
2 & Jadwal dan waktu & 0,85 & $42,63 \%$ \\
3 & Sumber dan alat penunjang & 0,87 & $43,32 \%$ \\
4 & Proses bimbingan & 0,85 & $42,48 \%$ \\
& Pengumpulan tugas struktur & 0,87 & $43,42 \%$ \\
& Nilai Ideal & 2 & $100 \%$ \\
\hline
\end{tabular}

Berdasarkan hasil perhitungan, diperoleh deskripsi indikator lingkup pemahaman dan tujuan pengerjaan memiliki presentase sebesar $43,86 \%$ dari kriteria sedang. Indikator jadwal dan waktu memiliki persentase sebesar 42,63\% dari kriteria sedang. Untuk sumber dan alat penunjang persentasenya sebesar $43,32 \%$ dari kriteria sedang, kemudian indikator proses bimbingan memiliki persentase sebesar sebesar $42,48 \%$ dari kriteria sedang dan indikator pengumpulan tugas struktur memiliki presentase sebesar $43,42 \%$ dari kriteria sedang.
Jadi, secara keseluruhan gambaran penyelesaian tugas terstruktur mahasiswa Prodi Pendidikan Teknik Bangunan memiliki persentase $43,42 \%$ yang termasuk ke dalam kriteria sedang.

\section{Hasil Uji Regresi}

Dari hasil perhitungan (Lampiran 2.10) diperoleh persamaan regresi $Y$ atas $\mathrm{X}$ sebagai berikut:

$$
\hat{Y}=a+b x=27,91+0,442 \mathrm{X}
$$

Berikut diagram pencar dan persamaan garis regresi:

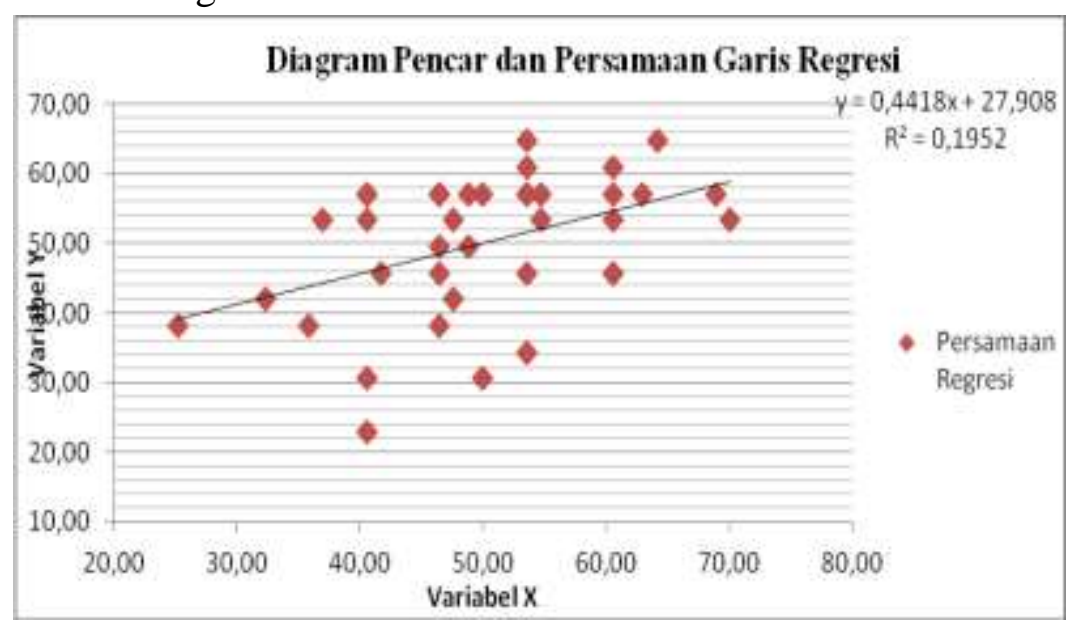

Gambar 1. Diagram Pencar dan Persamaan Garis Regresi 


\section{a. Uji Keberartian Regresi}

Sedangkan untuk uji keberartian regresi dari hasil perhitungan (Lampiran 2.10) diperoleh $F_{\text {hitung }}=8,733$, hasil tersebut kemudian dibandingkan pada tabel distribusi $\mathrm{F}$, sehingga diperoleh harga $F_{\text {tabel }}$ yaitu $F_{(0,95)(1,36)}=4,113$. Ternyata $\mathrm{F}_{\text {hitung }}>$ dari $\mathrm{F}_{\text {tabel }}$ maka dapat disimpulkan bahwa arah regresi nyata pada taraf kepercayaan 95\%, dengan derajat kebebasan $(\mathrm{dk})$ pembilang 1 dan penyebut 36.

\section{Analisis Koefisien Korelasi}

Berdasarkan pada kriteria penafsiran tingkat hubungan antar variabel, menunjukkan indeks korelasi 0,442) berada pada interval $0,40-0,59$ yang berarti mempunyai indeks korelasi sedang. Hal tersebut dapat diartikan bahwa kecerdasan emosional mempunyai hubungan yang sedang atau cukup dengan penyelesaian tugas terstruktur mahasiswa Prodi Pendidikan Teknik Bangunan UPI.

Besarnya konstribusi variabel $\mathrm{X}$ terhadap variabel $\mathrm{Y}$ dihitung dengan rumus Koefisien Diterminasi (KD), yaitu :

$$
\begin{aligned}
\mathrm{r}_{\mathrm{s}} & =0,442 \\
\mathrm{KD} & =\mathrm{r}_{\mathrm{s}}^{2} \times 100 \% \\
& =(0,442)^{2} \times 100 \% \\
& =19,52 \%
\end{aligned}
$$

\section{Hasil Uji Hipotesis}

Di dalam kajian ini hipotesis yang akan diuji adalah sebagai berikut : Gambaran mengenai Kecerdasan Emosional

Tabel 3. Uji Hipotesis

\begin{tabular}{ccc}
\hline \multicolumn{3}{c}{ Uji Hipotesis } \\
\hline Uji Kecenderungan & $\bar{X}$ & Keterangan \\
44,966 & 50,00 & Ho diterima dan Ha ditolak \\
\hline
\end{tabular}

Dasar pengambilan keputusan dengan membandingkan nilai $\mathrm{X}_{1}$ dengan $\bar{x}$. Apabila $\mathrm{X}_{1} \geq \bar{x}$ maka Ho ditolak, artinya baik sedangkan $\mathrm{X}_{1} \leq \bar{x}$ maka Ho diterima, artinya tidak baik. Dari hasil perhitungan uji kecendrungan diperoleh $\mathrm{X}_{1}$ sebesar 44,966 dan $\bar{x}$ sebesar 50, maka
Ho diterima yang artinya bahwa gambaran kecerdasan emosional mahasiswa prodi Pendidika Teknik Bangunan UPI dalam kategori tidak baik.

- Gambaran mengenai Penyelesaian Tugas Terstruktur

Tabel 4. Uji Hipotesis

\begin{tabular}{ccc}
\hline \multicolumn{3}{c}{ Uji Hipotesis } \\
\hline Uji Kecenderungan & $\bar{X}$ & Keterangan \\
55,404 & 50,00 & Ho ditolak dan Ha diterima \\
\hline
\end{tabular}

Dasar pengambilan keputusan dengan membandingkan nilai $\mathrm{X}_{1}$ dengan $\bar{x}$. Apabila $\mathrm{X}_{1} \geq \bar{x}$ maka Ho ditolak, artinya baik sedangkan $\mathrm{X}_{1} \leq \bar{x}$ maka Ho diterima, artinya tidak baik. Dari hasil perhitungan uji kecendrungan diperoleh $\mathrm{X}_{1}$ sebesar 55,404 dan $\bar{x}$ sebesar 50, maka Ho ditolak dan Ha diterima yang artinya 
Pengaruh Kecerdasan Emosional... (Sri/ hal. 24-36)

bahwa gambaran penyelesaian tugas terstruktur mahasiswa prodi Pendidika Teknik Bangunan UPI dalam kategori baik.
- Pengaruh positif dan signifikan antara kecerdasan emosional terhadap penyelesaian tugas terstruktur

Tabel 5. Uji Hipotesis

\begin{tabular}{ccc}
\hline \multicolumn{3}{c}{ Uji Hipotesis } \\
\hline $\mathrm{t}_{\text {hitung }}$ & $\mathrm{t}_{\text {tabel }}$ & Ket \\
2,955 & 2,028 & Signifikan \\
\hline
\end{tabular}

Berdasarkan tabel konsultasi untuk distribusi $\mathrm{t}$ diperoleh $\mathrm{t}$ tabel $=2,028$ dengan taraf kepercayaan $95 \%$ dan $\mathrm{dk}=$ $\mathrm{n}-2=36$, sehingga dapat disimpulkan thitung lebih besar dari $t_{\text {tabel }}\left(t_{\text {hitung }}=2,955>t_{\text {tabel }}=\right.$ 2,028), maka Ho ditolak dan Ha diterima, dapat diinterpretasikan bahwa terdapat pengaruh positif dan signifikan antara kecerdasan emosional dengan penyelesaian tugas terstruktur mahasiswa Prodi Pendidikan Teknik Bangunan UPI.

\section{Kecerdasan Emosional}

\section{a. Aspek Mengenali Emosi Orang}

Gambaran per indikator dari aspek mengenali emosi diri dapat ditunjukkan pada tabel di bawah ini :

Tabel 6. Gambaran Umum Per Indikator dari Aspek Mengenali Emosi Diri

\begin{tabular}{clcc}
\hline No & Indikator & Rata-Rata & Persentase \\
\hline \multirow{2}{*}{1} & $\begin{array}{l}\text { Mampu mengenali emosi yang sedang dirasakan } \\
\text { diri sendiri }\end{array}$ & 2,79 & $55,79 \%$ \\
2 & $\begin{array}{l}\text { Mampu mengenali kadar perasaan dengan } \\
\text { tindakan. }\end{array}$ & 2,87 & $57,37 \%$ \\
3 & Mampu mengenali kepercayaan diri & 2,53 & $50,53 \%$ \\
Aspek & Mengenali emosi diri & 2,68 & $53,68 \%$ \\
& $\quad$ Nilai Ideal & 5 & $100 \%$ \\
\hline
\end{tabular}

Dari perhitungan sebelumnya aspek mengenali emosi diri sebesar 53,68\% dari yang diharapkan. Aspek mengenali emosi diri ini masuk dalam kategori sedang.

Untuk meningkatkan aspek mengenali emosi tersebut, mahasiswa harus berfikiran positif dalam bertindak ataupun bersikap dan dapat menjaga agar emosi yang muncul dapat terkendali, ini merupakan kunci menuju kesejahteraan emosi dengan terlebih dahulu mendengarkan masukan-masukan positif dari berbagai pihak kemudian memutuskan sesuatu ataupun melakukan memperbanyak ibadah dan mendekatkan diri kepada Tuhan Yang Mahakuasa adalah cara yang paling efektif ataupun mengisi waktu dengan memperbanyak wawasan dengan membaca ataupun mengerjakan hal-hal yang bermanfaat sehingga dapat memperkecil hal-hal negatif dengan kegiatan yang berguna.

\section{b. Aspek Mengelola Emosi}

Gambaran per indikator dari aspek mengelola emosi dapat ditunjukkan pada tabel di bawah ini : 
Pengaruh Kecerdasan Emosional... (Sri/ hal. 24-36)

Tabel 7. Gambaran Umum Per Indikator dari Aspek Mengelola Emosi

\begin{tabular}{|c|c|c|c|}
\hline No & Indikator & Rata-Rata & Persentase \\
\hline 1 & Mampu untuk mengendalikan diri & 2,75 & $55,09 \%$ \\
\hline 2 & $\begin{array}{l}\text { Mampu memusatkan perhatian pada } \\
\text { kegiatan yang sedang berlangsung }\end{array}$ & 3,06 & $61,23 \%$ \\
\hline 3 & $\begin{array}{l}\text { Mampu menunda kesenangan sesaat } \\
\text { untuk mendapatkan hasil yang baik }\end{array}$ & 2,42 & $48,42 \%$ \\
\hline Aspek & Mengelola emosi & 2,74 & $54,74 \%$ \\
\hline & Nilai Ideal & 5 & $100 \%$ \\
\hline
\end{tabular}

Dari perhitungan sebelumnya aspek mengelola emosi sebesar $54,74 \%$ dari yang diharapkan. Aspek mengenali emosi diri ini masuk dalam kategori sedang.

Untuk meningkatkan aspek mengelola emosi tersebut, mahasiswa harus mampu mengendalikan emosinya agar tidak larut dalam perasaan, peka terhadap perasaannya, dan melepaskan dirinya dari suasana hati yang jelek dengan cara menunda sejenak pekerjaan atau hal yang membuatnya timbul perasaan negatif, misalnya menyalurkan hobi / refreshing sejenak ataupun melakukan hal-hal yang membuat dia bisa mengalihkan perasaan negatifnya sampai mood-nya kembali normal. Setelah itu mencari perspektif baru agar perasaan negatif/emosi tidak timbul kembali dan belajar dari kesalahan sehingga mengetahui yang mana yang mau diperbaiki.

\section{c. Aspek Memotivasi Diri Sendiri}

Gambaran per indikator dari aspek mengelola emosi dapat ditunjukkan pada Tabel 8.
Dari perhitungan sebelumnya aspek memotivasi diri sendiri sebesar 58,82\% dari yang diharapkan. Aspek memotivasi diri sendiri ini masuk dalam kategori sedang.

Untuk meningkatkan aspek memotivasi diri sendiri tersebut, mahasiswa belajar untuk memanfaatkna waktu secara maksimal dengan membuat jadwal serta membiasakan diri untuk melaksanakannya, mulai dari jadwal mengerjakan tugas, belajar sampai dengan jadwal bermain atau hang out dengan teman-teman. Mengisi kegiatan yang berdampak positif dan bermanfaat khususnya dapat menguatkan motivasi diri seperti menonton acara Mario Teguh Golden Ways, Kick Andy, dan seminarseminar yang berhubungan dengan motivasi diri sehingga secara tidak langsung motivasi akan muncul dengan sendirinya.

Tabel 8. Gambaran Umum Per Indikator dari Aspek Memotivasi Diri Sendiri

\begin{tabular}{clcc}
\hline No & \multicolumn{1}{c}{ Indikator } & Rata-Rata & Persentase \\
\hline 1 & Dorongan untuk berprestasi & 2,78 & $55,53 \%$ \\
2 & Mampu untuk optimis & 3,11 & $62,11 \%$ \\
Aspek & Memotivasi diri sendiri & 2,94 & $58,82 \%$ \\
& Nilai Ideal & 5 & $100 \%$ \\
\hline
\end{tabular}


Pengaruh Kecerdasan Emosional... (Sri/ hal. 24-36)

\section{d. Aspek Mengenali Emosi Orang Lain}

Gambaran per indikator dari aspek mengenali emosi orang lain dapat ditunjukkan pada Tabel 9.

Dari perhitungan sebelumnya aspek mengenali emosi orang lain sebesar $58,03 \%$ dari yang diharapkan. Aspek memotivasi diri sendiri ini masuk dalam kategori sedang.

Untuk meningkatkan aspek mengenali emosi orang lain tersebut, mahasiswa harus peka terhadap bahasa isyarat karena emosi lebih sering diungkapkan melalui bahasa isyarat, ikut merasakan, dan mengontrol emosi untuk menyadari dirinya sedang berempati. Memahami perasaan orang lain dengan bertoleransi dengan sesama ataupun menjadi pendengar yang baik apabila teman sedang mengalami kesulitan dan memberikan masukan-masukan untuk memecahkan masalah yang dialami oleh orang lain secara bersama.

Tabel 9. Gambaran Umum Per Indikator dari Aspek Mengenali emosi orang lain

\begin{tabular}{|c|c|c|c|}
\hline No & Indikator & Rata-Rata & Persentase \\
\hline 1 & Mampu merasakan perasaan orang lain & 2,71 & $54,21 \%$ \\
\hline 2 & Menerima atau mengerti perspektif orang lain & 3,09 & $61,84 \%$ \\
\hline Aspek & Mengenali emosi orang lain & 2,90 & $58,03 \%$ \\
\hline & Nilai Ideal & 5 & $100 \%$ \\
\hline
\end{tabular}

\section{e. Aspek Membina Hubungan}

Gambaran per indikator dari aspek membina hubungan dapat ditunjukkan pada Tabel 10.

Dari perhitungan sebelumnya aspek membina hubungan sebesar 60,59\% dari yang diharapkan. Aspek membina hubungan ini masuk dalam kategori sedang.

Untuk meningkatkan aspek membina hubungan tersebut, mahasiswa harus membangun hubungan sosial dengan lebih terbuka saat berkomunikasi dengan teman, mampu membawa diri (berbaur) atau tidak membeda-bedakan teman pada saat bergaul, membawa pengaruh yang lebih baik bagi orang lain dan mampu berkomunikasi dengan baik. Sehingga orang lain merasa nyaman berdekatan dengan kita.

\section{Penyelesaian Tugas Terstrtuktur \\ a. Proses Penyelesaian Tugas Terstruktur dan Ketepatan Waktu Pengumpulan}

Gambaran per indikator dari aspek pemahaman dan tujuan pengerjaan dapat ditunjukkan pada Tabel 11.

Dari perhitungan sebelumnya aspek proses penyelesaian tugas terstruktur dan ketepatan waktu pengumpulan sebesar 43,14\% dari yang diharapkan. Aspek mengenali emosi diri ini masuk dalam kategori sedang.

Tabel 10. Gambaran Umum Per Indikator dari Aspek Membina Hubungan

\begin{tabular}{clcc}
\hline No & \multicolumn{1}{c}{ Indikator } & Rata-Rata & Persentase \\
\hline 1 & Dapat memulai dan mempertahankan interaksi & 2,68 & $53,68 \%$ \\
2 & Mampu menyatakan emosi melalui komunikasi yang sesuai & 3,26 & $65,26 \%$ \\
3 & $\begin{array}{l}\text { Mampu menyesuaikan emosi dengan tepat dalam berinteraksi } \\
\text { dengan orang lain. }\end{array}$ & 3,05 & $61,05 \%$
\end{tabular}


Pengaruh Kecerdasan Emosional... (Sri/ hal. 24-36)

\begin{tabular}{|c|c|c|c|}
\hline No & Indikator & Rata-Rata & Persentase \\
\hline 4 & Mampu membaca situasi dalam hubungan interpersonal & 3,12 & $62,37 \%$ \\
\hline Aspek & Membina hubungan & 3,03 & $60,59 \%$ \\
\hline & Nilai Ideal & 5 & $100 \%$ \\
\hline
\end{tabular}

Tabel 11. Gambaran Umum Per Indikator dari Aspek Proses Penyelesaian Tugas Tesrtruktur dan Ketepatan Waktu Pengumpulan

\begin{tabular}{|c|c|c|c|}
\hline No & Indikator & Rata-Rata & Persentase \\
\hline Indikator 1 & Lingkup pemahaman dan tujuan pengerjaan & 0,88 & $43,86 \%$ \\
\hline Indikator 2 & Jadwal dan waktu & 0,85 & $42,63 \%$ \\
\hline Indikator 3 & Sumber dan alat penunjang & 0,87 & $43,32 \%$ \\
\hline Indikator 4 & Proses bimbingan & 0,85 & $42,48 \%$ \\
\hline Indikator 5 & Pengumpulan tugas struktur & 0,87 & $43,42 \%$ \\
\hline \multirow[t]{2}{*}{ Aspek } & $\begin{array}{l}\text { Proses penyelesaian tugas terstruktur dan } \\
\text { ketepatan waktu pengumpulan }\end{array}$ & 0,86 & $43,14 \%$ \\
\hline & Nilai Ideal & 2,00 & $100,00 \%$ \\
\hline
\end{tabular}

Untuk meningkatkan aspek proses penyelesaian tugas terstruktur dan ketepatan waktu pengumpulan, mahasiswa harus memahami tahapan dalam mengerjakan tugas sehingga mengetahui sistematikanya, dapat mengatur waktu pengerjaan tugas dengan kegiataan di luar dengan membuat jadwal serta membiasakan diri untuk melaksanakannya, kemudian mencari atau menambahkan buku penunjang dalam pengerjaan tugas atau bertanya kepada kakak tingkat apabila kesulitan dalam pengerjaan tugas.

\section{Pengaruh Kecerdasan Emosional Terhadap Penyelesaian Tugas Terstruktur \\ Berdasarkan hasil perhitungan} Koefisien Determinasi (KD) untuk mengetahui seberapa besar kontribusi kecerdasan emosional terhadap penyelesaian tugas terstruktur mahasiswa dapat disimpulkan bahwa kecerdasan emosional memberikan kontribusi sebesar $19,52 \%$ terhadap penyelesaian tugas terstruktur, hal ini disebabkan karena mahasiswa kurang menguasai pengetahuan mengenai kecerdasan emosional dalam penyelesain tugas terstruktur sehingga cenderung dalam melakukan segala aktivitas sesuai dengan mood bukan dengan nalar atau logika, dalam pengerjaan tugas terstrukturpun cenderung mahasiswa kurang konsentrasi sehingga hasilnyapun kurang maksimal. Sedangkan sisanya 80,48\% dipengaruhi oleh fakor lain. Faktor lain tersebut di antaranya adalah yang disebutkan dalam identifikasi masalah

\section{SIMPULAN}

Gambaran umum mengenai kecerdasan emosional mahasiswa prodi Pendidikan Teknik Bangunan UPI tergolong dalam kriteria sedang. Kecerdasan emosional dilihat dari aspek mengenali emosi diri, mengelola emosi, memotivasi diri sendiri, mengenali orang lain dan membina hubungan. Gambaran umum mengenai penyelesaian tugas terstruktur mahasiswa prodi Pendidikan Teknik Bangunan UPI tergolong dalam kriteria sedang. Penyelesaian tugas 
Pengaruh Kecerdasan Emosional... (Sri/ hal. 24-36)

terstruktur dilihat dari aspek proses penyelesaian tugas terstruktur dan ketepatan waktu pengumpulan. Hasil uji hipotesis melalui analisis korelasi menunjukkan bahwa kecerdasan emosional berpengaruh positif dan signifikan terhadap penyelesaian tugas terstruktur dengan kriteria sedang.

\section{DAFTAR RUJUKAN}

Agustin, Ary Ginanjar. (2004). ESQ Power Sebuah Inner Journey Melalui Al-Ihsan. Jakarta: Arga.

Arif, B. (2009). Hubungan antara Kecerdasan Emosional dengan Prestasi Belajar pada Siswa SMK Negeri 1 Cimahi. Skripsi Sarjana pada Jurusan Psikologi. Universitas Pendidikan Indonesia Bandung: tidak diterbitkan.

Arikunto, Suharsimi. (2010). Prosedur Penelitian: Suatu Pendekatan dan Praktik. Jakarta: Rineka Cipta.

Arikunto, Suharsimi. (2002). Manajemen Penelitian. Jakarta: Rineka Cipta.

Dahliani, Lia. (2008). Faktor-faktor yang Mempengaruhi Terhambatnya Penyelesaian Tugas Terstruktur Teknik Irigasi 1 di Program Studi Studi Pendidikan Teknik Sipil UPI. Skripsi sarjana UPI. Bandung : Tidak diterbitkan.

Depdikbud. (2005). Kamus Besar Bahasa Indonesia. Jakarta: Balai Pustaka.

Goleman, Daniel. (2005). Kecerdasan Emosi Untuk Mencapai Puncak
Prestasi. Jakarta: PT Gramedia Pustaka Utama.

Goleman, Daniel. (2007). Kecerdasan Emosional: Mengapa EI lebih penting daripada IQ. Jakarta: PT Gramedia Pustaka Utama.

Hamalik, Oemar. (1986). Teknik Pengukuran dan Evaluasi Pendidikan. Bandung: Pustaka Martiana

Kurniansyah, Imam Firdaus. (2007). Pengaruh antara Kecerdasan Emosional dengan Prestasi Belajar Mata Kuliah Mekanika Teknik. Skripsi Sarjana UPI: tidak diterbitkan.

Mudjijana, Romanus. (2004). "Hubungan Antara Iklim Sekolah dan Kecerdasan Emosional Siswa dengan Prestasi Belajar Siswa". Journal Pendidikan Penabur. 02, 82-100.

Nazir, M. (1983). Metode Penelitian. Jakarta: Ghalia Indonesia.

Nok, Acu. (2011). Pengaruh Persepsi Mahasiswa Tentang Penyelesaian Tugas Terstruktur Terhadap Prestasi Belajar Pada Mata Kuliah Rencana Anggaran Biaya. Skripsi Sarjana pada Jurusan Pendidikan Teknik Sipil. Universitas Pendidikan Indonesia Bandung: tidak diterbitkan.

Pedoman Akademik UPI. (2019). Menyongsong Hari Esok. Bandung: 
Pengaruh Kecerdasan Emosional... (Sri/ hal. 24-36)

Tidak diterbitkan terbatas untuk lingkungan UPI.

Puspa, R. (2011). Hubungan antara Kecerdasan Emosional dengan Penyesuaian Sosial. Skripsi Sarjana pada Jurusan Psikologi. Universitas Pendidikan Indonesia Bandung: tidak diterbitkan.

Riduwan. (2004). Belajar Mudah Penelitian untuk Guru-Karyawan dan Peneliti Pemula. (Edisi Keenam). Bandung: Alfabeta.

Riduwan \& Sunarto. (2009). Pengantar Statistika untuk Penelitian Pendidikan, Sosial, Ekonomi, Komunikasi, dan Bisnis. Bandung: Alfabeta.

Sugiyono. (2010). Metode Penelitian Bisnis. Bandung: Alfabeta.

Sugiyono. (2009). Statistik untuk Penelitian. (Edisi Kelima Belas). Bandung: Alfabeta.

Sugiyono. (2007). Metode Penelitian: Pendekatan Kuantitatif, Kualitatif, dan $R \& D$. Bandung: Alfabeta.

Sudjana. (2002). Metode Statistika. Bandung: Tarsito

Surakhmad, W. (1990). Pengantar Penelitian Ilmiah. Bandung: Tarsito.

Syamsudin, Abin. (2002). Psikologi Kependidikan. Bandung: Rosda Karya.
Tim Penyusun. (2019). Pedoman Penulisan Karya Ilmiah. Bandung: Universitas Pendidikan Indonesia.

Triyono, B. M., Mohib, N., Kassymova, G. K., Pratama, G. N., Adinda, D., \& Arpentieva, M. R. (2020). The Profile Improvement of Vocational School Teachers' Competencies. Vysshee obrazovanie $v$ Rossii= Higher Education in Russia, 29(2), 151-158.

Yuningsih, Amy Aminah. (2009). Faktorfaktor yang Mempengaruhi Terhambatnya Pembelajaran Mahasiswa Program Studi Pendidikan Teknik Sipil UPI. Skripsi sarjana UPI. Bandung: Tidak diterbitkan.

Zainun, Mu'tadin. (2002, 25 April). Mengenal Kecerdasan emosional remaja. E-Psikologi [Online]. Tersedia: http://e-psikologi.com 